\title{
SyPhacia longaecauda N. SP. (Nematoda: Oxyuridae) SyPHACINEA fROM MElomys SPP. (MURIdaE: Hydromyinae) from Papua New GuINea and IRIAN JaYA, INDONESIA
}

\author{
SMALES L.R.*
}

\section{Summary :}

A new oxyurid nematode Syphacia (Syphacia) longaecauda n. sp. is described from the caecum and colon of the hydromyine rodents Melomys monktoni (type host) and M. rubex from Papua New Guinea and Irian Jaya, Indonesia. Syphacia longaecauda has an oval, laterally extended, relatively large cephalic plateau and can be distinguished from other species of Syphacia with similar characters by, amongst other features, tail length. The significance of the distribution of S. longaecauda, apparently restricted to New Guinea, is discussed.

KEY WORDS : Nematoda, Oxyuridae, Syphacia, murid, hydromyine, Melomys, Papua New Guinea, Irian Jaya, biogeography.
Résumé : SYPHACLA LONGAECAUDA N. SP. (NEMATODA : OXYURIDAE) Syphacinea de Melomys SpP. (Muridae : HydromyinaE) DE Papouasie Nouvelle-GuinéE et IndonÉSIE

Une nouvelle espèce d'oxyure, Syphacia (Syphacia) longaecauda n. sp., est décrite au niveau du caecum et de l'intestin grêle des rongeurs hydromyinés Melomys monktoni (hôte type) et $M$. rubex de Nouvelle Guinée et d'Indonésie Irian Jaya. Syphacia longaecauda possède un plateau céphalique qui est relativement grand, ovale, et prolongé latéralement. Elle peut être distinguée des autres espèces de Syphacia qui possèdent des caractères semblables par la longueur de la queve. L'importance de la distribution de cette espèce, apparemment limitée à la Nouvelle Guinée, est discutée.

MOTS CLÉS : Nematoda, Oxyuridae, Syphacia, Muridae, Hydromyinae, Melomys, Papouasie Nouvelle Guinée, Irian Jaya, Indonésie, biogéographie.

\section{INTRODUCTION}

$\mathrm{D}$ uring investigations into the helminth fauna of endemic rodents from the island of New Guinea specimens of an oxyurid (Nematoda: Oxyuridae) were found in individuals of Melomys monktoni Thomas, 1904 and Melomys rubex Thomas, 1922 collected in Irian Jaya, Indonesia and Papua New Guinea. Having characters typical of the genus Syphacia that occurs in rodents (Hugot, 1988) these specimens were sufficiently different to be considered a new species, described below.

\section{MATERIAL AND METHODS}

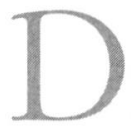
igestive tracts from whole bodies of Melomys sp. which had previously been collected and stored in $70 \%$ ethanol in the Bernice Bishop Museum, Honolulu, Hawaii (BBM), and The Australian Museum, Sydney, (AM) were removed and examined

\footnotetext{
* School of Biological and Environmental Sciences, Central Queensland University, Rockhampton, Queensland 4700, Australia. Correspondence: Lesley Warner.

Tel.: 001161749309641 - Fax: 001561749309209.

E-mail: l.warner@cqu.edu.au
}

for helminths. All parasites found were stored in $70 \%$ ethanol prier to clearing in lactophenol for identification. Measurements of 10 specimens of each sex taken using an ocular micrometer, are given as the range followed by the mean in parentheses, in micrometers unless otherwise stated. Drawings were made with the aid of an Olympus microscope drawing tube. The rodent bodies have remained in the museums in which they were registered and all helminth specimens have been deposited in the BBM, AM or South Australian Museum, Adelaide (SAM). The terminology used follows Quentin (1971) and Hugot (1988).

\section{RESULTS}

\section{SYPHACIA (SYPHACIA) LONGAECAUDA SP. N.} (Figs 1-13)

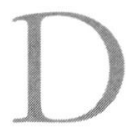

escription: small nematodes, typical oxyurid shape, with transverse cuticular striations. Cephalic inflation distinct. Cephalic plateau oval, extended laterally in en face view; amphids situated between cephalic papillae on the two lateral projections; mouth opening simple, three pseudo-labia rather shallow. Oesophagus with distinct isthmus, terminating in a spherical bulb. Excretory pore posterior to oesophageal bulb. 

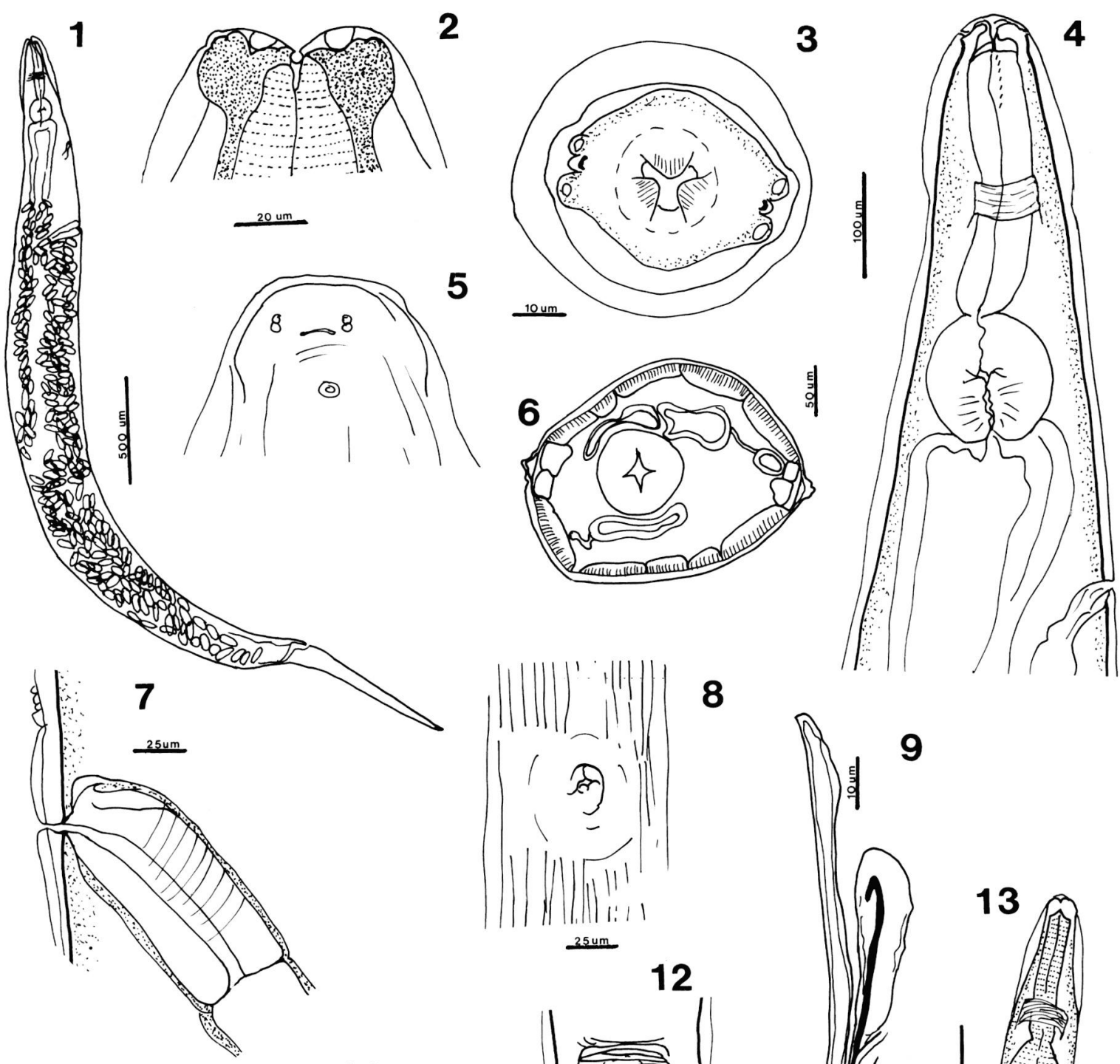

8
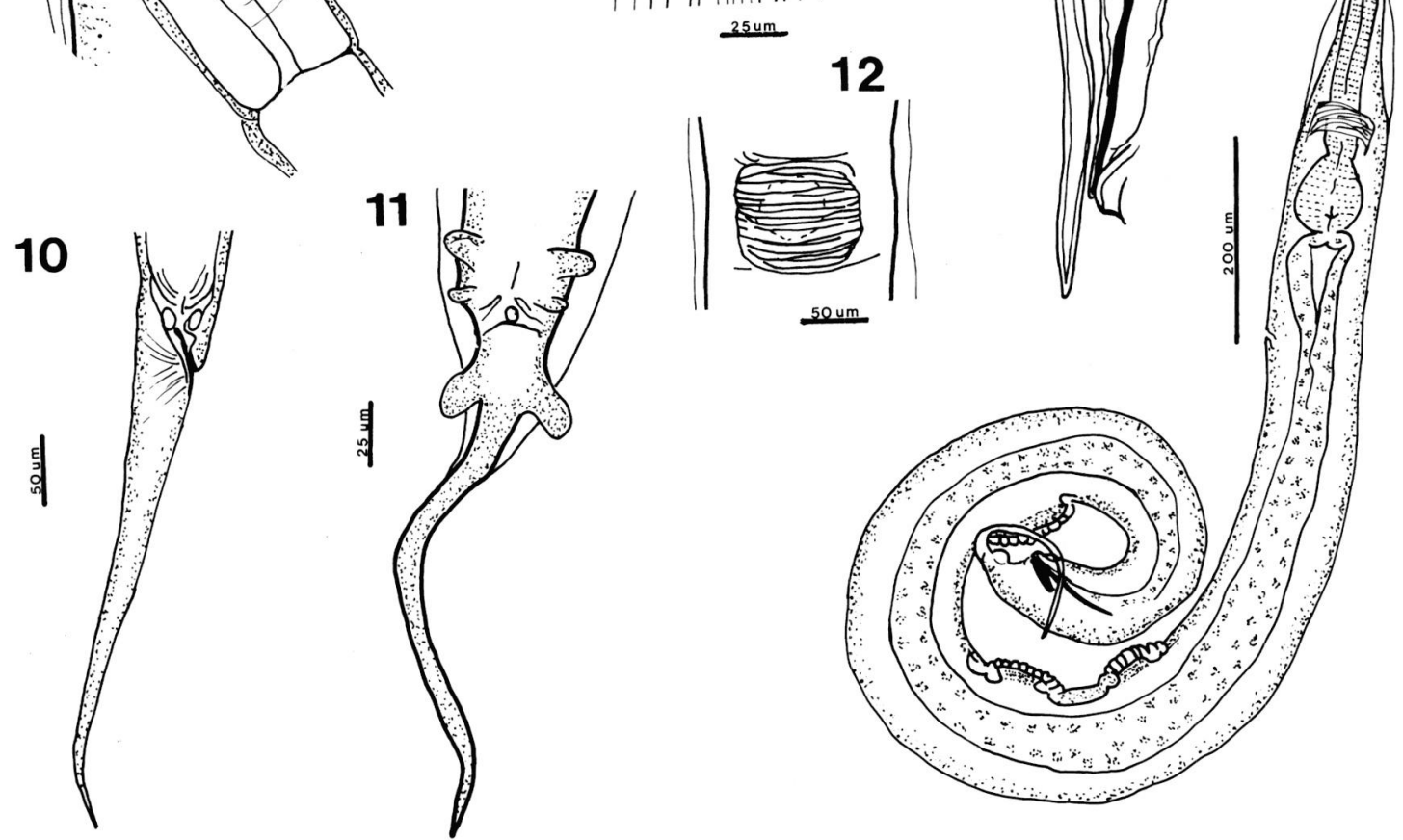

Figs 1-13. - Syphacia (Syphacia) longaecauda n. sp.

1. Female, right lateral view. 2. Cephalic end of female ventral view, optical section. 3. En face view of female. 4. Anterior end of female, right lateral view. 5. Cephalic end of male, left lateral view. 6. Hand cut transverse section of female, at level of oesophagus. 7. Vagina, left lateral view. 8. Vulva, ventral view. 9. Spicule and gubernaculum. 10. Female tail, left lateral view. 11. Male tail, ventral view. 12. Mamelon, ventral view. 13. Male, left lateral view. 
Male: Length 1.6-2.05 (1.8) mm, maximum width 102156 (125). Oesophagus 240-355 (287) long; oesophageal bulb 60-93 (74) in diameter. Nerve ring 111-148 (126), excretory pore 375-436 (390) from anterior end Three mamelons with prominent annulations, spines not observed; first mamelon 80-90 (84) long, 600-850 (728) from anterior end; second mamelon 70-85 (79) long, 100-225 (115) behind first; third mamelon $70-90$ (78) long, 250-425 (305) behind second. Tail 370-490 (430) long. Spicule needle shaped 76-97 (85) long; gubernaculum 39-47 (41) long; ventral barb not observed. Two pairs preanal, one pair large caudal papillae.

Female: Length 4.0-4.4 (4.3) mm, maximum width 306357 (342). Oesophagus 408-456 (431) long; oesophageal bulb 121-127 (123) in diameter. Nerve ring 119127 (121); excretory pore 470-636 (550); vulva 765-986 (915) from anterior end. Tail 616-850 (740) long. Eggs, 94-100 (97) by 34-42.5 (39).

Type host: Melomys monktoni: Thomas, 1904 (Muridae: Hydromyinae).

Site of Infection: caecum and colon.

Prevalence: three of nine M. monktoni, 10 of 31 M. mubex Type locality: Bulldog Road 12 miles south of Edie Creek Morobe Province, Papua New Guinea, coll. A.B. Mirza 13. vii 1972.

Deposition of types: holotype $\delta$ allotype + SAM AHC 31373, AHC 31374, paratypes AHC 31375, BBM reg no 101220 .

Etymology: the specific name refers to the long tail characteristic of this species.

Material examined: from Papua New Guinea: Melomys monktoni 4 q, 1 ô Mt Kaindi, Wau, coll. A.B. Mirza 24, viii. 1972 BBM 97688; 2 q, 1 of Bulldog Road six miles from Edie Creek, Morobe Province, coll. A.B. Mirza, 5. xii. 1970 BBM 99496. From Melomys rubex 3 ․, 1 o Bafunmin, Sandaun Province, coll. A.B. Mirza 30. iii. 1980 108087; 1 ô, 26 \& Bokubet, Sandaun Province, coll. T. Bukam, 7. vii. 1976 BBM 105251, 105232. 2 o, 11 \& Somoro summit, Toricelli Mts, Sandaun Province, coll. T. Flannery 6. vi. 1988, T. Ennis 7. i. 1988 AM W26276, W26277; 1 \%, Telefomin, Sanduan Province, coll. T. Flannery 6. vi. 1988 AM W26278; 5 ô, 24 우 Tifalmin, Sanduan Province, coll. T. Flannery 15. iv. 1986 AM W26280, W26281; 1 ㅇ, 1 o Dokfuma Star Mts, Sanduan Province, coll. T. Flannery 6. iv. 1987 AM W26282.

From Irian Jaya. Melomys rubex 1 \& Urong Forest, Arfak Mts, coll. T. Flannery AM W26279.

\section{DISCUSSION}

The specimens described herein belong to the genus Syphacia, (parasites of Cricetidae and Muridae) and the subgenus Syphacia Seurat,
1916. They have neither a rectangular shaped cephalic plateau and well developed triangular shaped lateral alae, as found in the subgenus Cricetoxyuris Hugot, 1988 nor a short conical tail characteristic of the subgenus Seuratoxyuris Hugot, 1988.

Of the 14 species comprising Syphacia (Syphacia), Syphacia (Syphacia) longaecauda n. sp. most closely resembles a group of Syphacia spp. S. arctica Tiner \& Rausch, 1950; S. montana Yamaguti, 1943; S. nigeriana Baylis, 1928; S. obvelata (Rud, 1802) and S. venteli Travassos, 1937; characterized as Group V by Quentin (1971); having an oval cephalic plateau bordered laterally by the submedian papillae. Syphacia longaecauda most closely resembles $S$. arctica, S. montana and $S$. obvelata in having a relatively large cephalic plateau measuring $45-50 \mu \mathrm{m}$ between the amphids but these species have cuticular embossing surrounding the cephalic plateau and S. longaecauda does not. Syphacia nigeriana and $S$. venteli have a smaller plateau, 30-40 $\mu \mathrm{m}$ between the amphids. Each of the species differs in en face view, S. longaecauda differing in particular from each of the other species in the group in the position of the amphids relative to the papillae (see Quentin, 1971). Furthermore S. longaecauda differs in one or more of the measurements of spicule, gubernaculum, eggs, or tail from the other species in the group (Table I).

Syphacia longaecauda also differs from the two species of Syphacia, S. darwini Hugo \& Quentin, 1985 and S. muris (Yamaguti, 1935) previously known from the region. Syphacia darwini has two rather than three mamelons. Syphacia muris has a square rather than oval cephalic plateau as found in S. longaecauda. The spicules and gubernaculum of $S$. longaecauda 76-97 and 39-47 are longer than those of $S$. muris 30-61 and 20-36 respectively. The male tail is longer 390-490 compared with 115-285 and the eggs are larger 94-100 $\times 32-43$ compared with $64-90 \times 23-40$ (Measurements of Ow Yang, 1971; Hugot \& Quentin, 1985; Hasegawa \& Tarore, 1996).

The tail of Syphacia longaecauda males is longer than that recorded for any species of Syphacia (Syphacia) thus far. Syphacia darwini is found in Melomys spp. hosts endemic to Australia (Hugot \& Quentin, 1985; Smales, 1997). Syphacia muris is a cosmopolitan species occurring in the cosmopolitan hosts Rattus rattus $\mathrm{L}$. and $R$. norvegicus (Berkenhout) as well as $R$. fuscipes Waterhouse, R. tunneyi (Thomas) and R. sordidus (Gould) from Australia (Smales, 1997). Syphacia longaecauda has been found only in Melomys spp. hosts endemic to Papua New Guinea and Irian Jaya.

The host genus Melomys Thomas, with four representatives found in Australia and 13 in Irian Jaya and Papua New Guinea, is referred to the polyphyletic tribe 


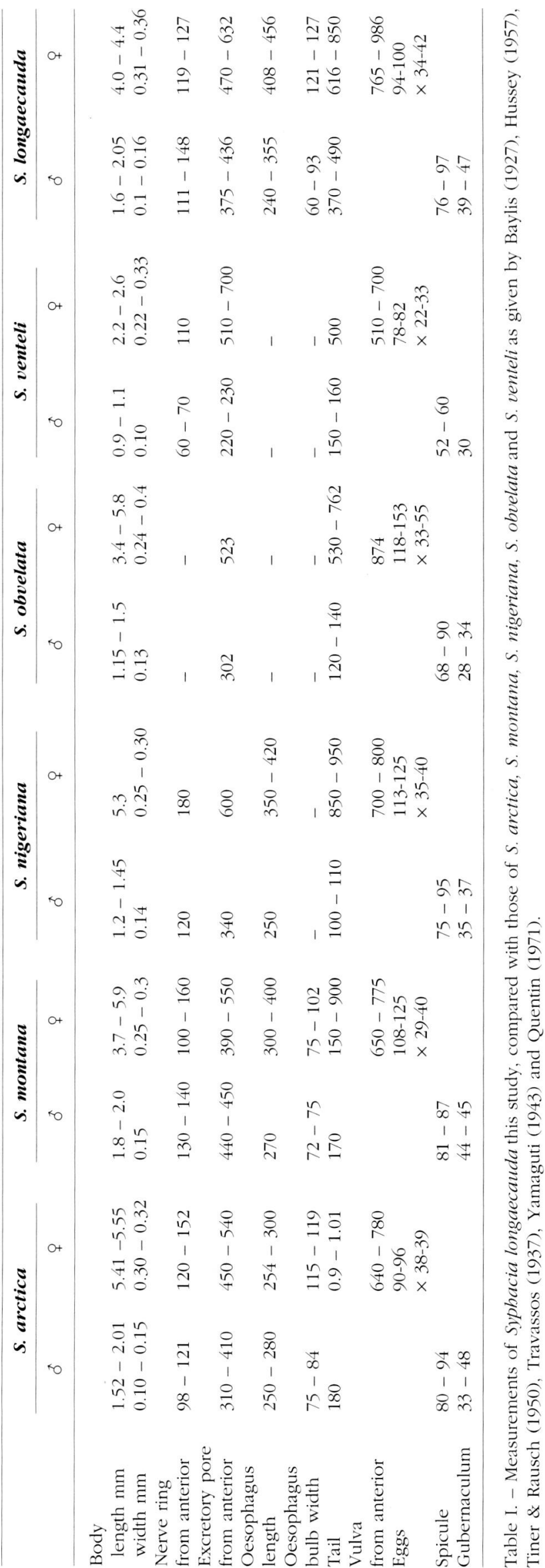

Uromyini Watts \& Aslin, 1981. This group is assumed to be derived from the earliest, possibly Miocene, murid invasion of New Guinea. Melomys is suggested to have subsequently migrated from New Guinea to Australia over land bridges between the two land masses that formed during The Pleistocene (Flannery, 1995). The finding of $S$. darwini only in Australian and now S. longaecauda only in New Guinean Melomys is indicative of speciation in Australia after Melomys migrated from New Guinea without any reverse migration. It may be, however, that these two species of Syphacia are sympatric since the helminth fauna of rodents in both areas is poorly known. Additional surveys of rodents across the region are needed before firm conclusions can be drawn.

\section{ACKNOWLEDGEMENTS}

$\mathrm{M}$ $y$ thanks go to T. Flannery and T. Ennis of the Australian Museum and C. Kishinami of The Bishop Museum for allowing me to dissect out Melomys bodies. This project was supported by an Australian Research Council Grant.

\section{REFERENCES}

BAYLIS H.A. On a collection of nematodes from Nigerian mammals (chiefly rodents). Parasitology, 1928, 20, 280-304.

FlanNery T. Mammals of New Guinea. Reed Books, Chatswood, 1995, $568 \mathrm{p}$.

Hasegawa H. \& TARORE D. Syphacia (Syphacia) sulawesiensis n. sp. and S. (S.) muris (Yamagati, 1935) (Nematoda: Oxyuridae) collected from Rattus xanthurus (Graf, 1867) (Rodentia: Muridae) in North Sulawesi, Indonesia. Tropical Zoology, 1996, 9, 165-173.

Hugot J.-P. Les nématodes Syphaciinae parasites de rongeurs et de lagomorphes. Mémoires du Muséum National d'Histoire Naturelle, Série A, 1988, 141, 1-148.

Hugot J.-P. \& Quentin J.-C. Étude morphologique de six espèces nouvelles ou peu connues appartenant au genre Syphacia (Oxyuridae: Nematoda), parasites de Rongeurs Cricétidés et Muridés. Bulletin du Museum National d'Histoire Naturelle, 4e Série, 1985, 7, 383-400.

Hussey K.L. Syphacia muris vs S. obvelata in laboratory rats and mice. Journal of Parasitology, 1957, 43, 554-559.

Ow YANG C.K. Studies on the nematode parasites of Malaysian rodents. I. The Rhabdiasidea, Trichuridea and Oxyuroidea. Journal of Helminthology, 1971, 45, 93-109.

Quentin J.-C. Morphologie comparée des structures céphaliques et génitales des oxyures du genre Syphacia. Annales de Parasitologie Humaine et Comparée, 1971, 46, $15-60$

SMALES L.R. A review of the helminth parasites of Australian rodents. Australian Journal of Zoology, 1997, 45, 505-521. 
Tiner J.D. \& Rausch R. Two new Syphacia (Nematoda: Oxyuridae) and observations on the inner circle circumoral papillae in North American species of the genus. Natural History Miscellanea, 1950, 57, 1-12.

Travassos L. Contribuicao ao conhecimento da phylogenia des Oxyuroidea (Nematoda). Memorias do Instituto Oswaldo Cruz, 1937, 32, 607-613

Watts C.H.S. \& Aslin H.J. The rodents of Australia. Angus \& Robertson, Sydney, 1981, 321 p.

Yamaguti S. Studies on the helminth fauna of Japan. Part 43. Mammalian nematodes, IV. Japanese Journal of Zoology, $1943,10,427-454$.

Reçu le 28 mars 2000

Accepté le 7 août 2000 